\title{
YOGHURTS WITH ADDITION OF SELECTED VEGETABLES: ACIDITY, ANTIOXIDANT PROPERTIES AND SENSORY QUALITY
}

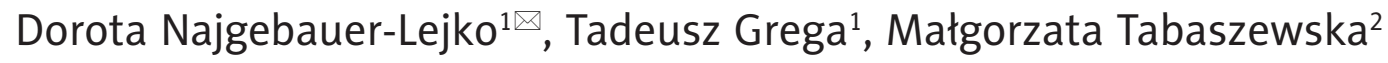 \\ ${ }^{1}$ Department of Animal Product Technology, University of Agriculture in Krakow \\ Balicka 122, 30-149 Krakow, Poland \\ 2Department of Raw Materials and Fruit and Vegetable Processing, University of Agriculture in Krakow \\ Balicka 122, 30-149 Krakow, Poland
}

\begin{abstract}
Background. Yoghurt is a fermented milk of unique sensory, nutritive and dietetic value offered in a variety of types and in different flavours. Vegetables belong to the group of food products rich in antioxidant substances (e.g., vitamin C, carotenoids, tocopherols, polyphenols) which regular consumption lowers the risk of many diseases including cancers and cardiovascular disorders. The aim of the present work was to manufacture and assess the acidity, sensory quality and antioxidant capacity of yoghurts with addition of selected vegetables during 2-week refrigerated storage.

Material and methods. The vegetable preparations (carrot, pumpkin, broccoli and red sweet pepper) were added to the cow's milk fermented using DVS type yoghurt culture after initial cooling to $15-20^{\circ} \mathrm{C}$ in the amount of $10 \%(\mathrm{w} / \mathrm{w})$. The following analyses were performed: determination of $\mathrm{pH}$, titratable acidity, antioxidant activity by ferric reducing antioxidant power (FRAP) and 2,2'-diphenyl-1-picrylhydrazyl (DPPH) method as well as sensory evaluation and were conducted after 1, 7 and 14 days of cold storage.

Results. The yoghurt supplementation with selected vegetables had no significant effect on the $\mathrm{pH}$ and titratable acidity level. The highest ability to scavenge DPPH radicals was stated for yoghurts with broccoli and red sweet pepper. The latter treatment gained the highest notes in sensory evaluation. All vegetable yoghurts were characterised by higher than the natural yoghurt FRAP values measured directly after production. However, the level of this parameter significantly decreased after storage.

Conclusions. The red sweet pepper additive was the most beneficial regarding antioxidant properties and organoleptic acceptance of the studied yoghurts.
\end{abstract}

Key words: DPPH, FRAP, vegetables, yoghurt, sensory quality

\section{INTRODUCTION}

Yoghurt is among the most popular fermented milk products consumed all over the world because of its excellent sensory properties, as well as high nutritive and therapeutic values. It is offered in a variety of types concerning fat and total solids content, the form of the body (drinking, set-style, frozen, concentrated), with or without additives, probiotic microflora and in different flavours [Grochulska 2008]. Yoghurts may also be fortified with bioactive components like: caffeine, guarana, green tea extract, coenzyme Q10, ginseng, aloe vera, cranberry, fibre [Stankiewicz 2009]. The most popular flavourings for yoghurts are of fruit types. Among non-traditional additives also vegetable powders, pulps and natural extracts obtained from raw 
vegetables have been used in the production of fermented milk products [Tamime and Robinson 1999]. The manufacturing process of food formulation containing milk or soy yoghurt and $30-70 \%$ pureed cooked vegetables was described by Shereshevsky [2005]. The therapeutic and prophylactic effect of cultured dairy products containing vegetable and fruit powders (beetroot, carrot, pumpkin, marrow, apple) for patients with gastrointestinal disorders was reported by Arkhipova et al. [1995].

Vegetables present a valuable source of nutrients and are also low in calories. They are rich in dietary fibre, minerals as well as many bioactive compounds, such as antioxidants, e.g. carotenoids, ascorbic acid, tocopherols, phenolic substances [Czapski 2001]. Biological antioxidants are substances which in low concentration are able to delay or prevent the oxidative damage of various biomolecules connected with various diseases including cancer, liver disease, Alzheimer's disease, aging, arthritis, inflammation, diabetes, Parkinson's disease, atherosclerosis and AIDS [Moon and Shibamoto 2009]. Increased fruit and vegetable consumption is an effective strategy to increase antioxidant intake and may help to prevent developing chronic diseases, especially cancer and cardiovascular disease [Song et al. 2010].

Supplementation of yoghurt with selected vegetables will provide additional health properties, especially concerning antioxidant properties and will result in the development of novel functional dairy products. The aim of the present study was to produce yoghurts with the addition of carrot, pumpkin, broccoli and red sweet pepper preparations and to determine the effect of selected vegetables on the fundamental chemical properties, acidity, antioxidant capacity and organoleptic acceptance of the obtained fermented milk products.

\section{MATERIAL AND METHODS}

Materials. Fresh cows' milk for yoghurt production was obtained from a local milk farm in Olszanica (Poland). Instant non-fat milk powder for milk standardisation was purchased from Dairy Company in Gostyn (Poland). A commercial YC-180 DVS yoghurt culture obtained from Chr. Hansen (Denmark) was used for milk inoculation. The fresh (pumpkin, broccoli, red pepper) or frozen (carrot, Hortex, Poland) vegetables were all purchased from the local market during the autumn period.

Vegetable preparation. The fresh broccoli, pumpkin and red sweet pepper were washed, pumpkin and pepper were peeled (pepper after short heating in the oven at $200^{\circ} \mathrm{C}$ ) and cut. All vegetables were cooked for 15-20 min in a small amount of water which was removed and then the vegetables were mixed to obtain homogenic preparations. The obtained vegetable pomaces were pasteurised in $200 \mathrm{ml}$ glass jars $\left(85-90^{\circ} \mathrm{C}\right.$, $15 \mathrm{~min}$ ), cooled and stored at $4^{\circ} \mathrm{C}$ prior to use.

Yoghurt manufacture. Raw milk before yoghurt preparation was centrifuged ( $2 \%$ fat), standardised to $5 \%$ protein content with NMP (non-fat milk powder), homogenised $\left(60^{\circ} \mathrm{C}, 6 \mathrm{MPa}\right)$, pasteurised $\left(85^{\circ} \mathrm{C}\right.$, $15 \mathrm{~min}$ ), cooled to $44^{\circ} \mathrm{C}$ and subsequently inoculated with the YC-180 DVS culture in a dose of $2 \%$ and poured into $200 \mathrm{~mL}$ sterile glass jars. The incubation proceeded at $43^{\circ} \mathrm{C}$ to the $4.7 \mathrm{pH}(6-7 \mathrm{~h})$. After that fermented milks were cooled to $15^{\circ} \mathrm{C}$ and mixed with $10 \%(\mathrm{w} / \mathrm{w})$ of the respective vegetable pomace, i.e.: carrot, pumpkin, broccoli and red sweet pepper using sterile spatula. The dosage of vegetable preparation was chosen from three different concentrations tested $(5,10,15 \%)$ for sensory acceptance in the preliminary study. Natural (control) yoghurt without vegetable supplementation was also produced and mixed. The yoghurts were kept at $4{ }^{\circ} \mathrm{C}$ and analysed after 1, 7 and 14 days of cold storage.

Analyses. In all samples the $\mathrm{pH}$ was measured using an Elmetron (Poland) CP-411 pH-meter equipped with a combination electrode ERH-111 (Hydromet, Poland). Titratable acidity expressed as \% of lactic acid was determined according to the Soxhlet-Henkel method [PN-A-86061:2002].

The antioxidant activity of yoghurts was evaluated using two different approaches. The scavenging rate of 2,2-diphenyl-1-picrylhydrazyl (DPPH) radical was measured by the procedure reported by Skrede et al. [2004] and expressed as anti radical power (ARP) in $\mu \mathrm{mol} \mathrm{TE} \cdot \mathrm{g}^{-1}$. The ferric reducing antioxidant power (FRAP) analysis was performed by the method described by Lucas et al. [2006].

The sensory evaluation was performed by a trained panel of 5 judges using a 5-point hedonic scale. The following properties were assessed: colour, taste, aroma, 
Najgebauer-Lejko D., Grega T., Tabaszewska M., 2014. Yoghurts with addition of selected vegetables: acidity, antioxidant properties and sensory quality. Acta Sci. Pol., Technol. Aliment. 13(1), 35-42.

consistency and general appearance. The overall preference was calculated taking into account the following indexes of importance for each quality attributes: 0.10 for colour, 0.35 for taste, 0.15 for aroma, 0.25 for consistency, 0.15 for general appearance [Domagała 2011].

All experiments were replicated three times and the analyses were done in duplicates. The results were expressed as mean \pm standard error. In order to estimate the effect of vegetable addition and time of storage on the acidity, antioxidant properties and sensory quality of yoghurts the obtained results were subjected to two-way analysis of variance and the significance of differences between the means was determined using Duncan test at the significance level of $P<0.05$. The statistical analysis was performed using Statistica 8.0 software (StatSoft, USA).

\section{RESULTS AND DISCUSSION}

The composition of the obtained yoghurts is given in Table 1. Yoghurts supplemented with vegetables were characterised by a lower concentration of dry matter, fat and protein compared to the plain yoghurt.

The titratable acidity and $\mathrm{pH}$ of the examined yoghurts ranged from 0.94 to $1.14 \%$ lactic acid and from 4.51 to 4.86 , respectively (Figs 1-2). It is in agreement with data reported by Tamime and Robinson [1999] that typical yoghurt should be characterised by an acidity in the range of $0.7-1.17 \mathrm{~g}$ lactic acid per $100 \mathrm{~g}$ of retail product as well as with the requirements of Polish Standard PN-A-86061:2002 (min. 0.6\% lactic acid). The average $\mathrm{pH}$ values of vegetable preparations were:

Table 1. The average composition of yoghurts, $\mathrm{g} \cdot 100 \mathrm{~g}^{-1}$

\begin{tabular}{lclc}
\hline \multicolumn{1}{c}{ Yoghurt type } & Dry matter & Fat & Protein \\
\hline Natural & $14.63^{\mathrm{a}}$ & $1.91^{\mathrm{a}}$ & $5.20^{\mathrm{a}}$ \\
With carrot & $14.17^{\mathrm{ab}}$ & $1.63^{\mathrm{ab}}$ & $4.74^{\mathrm{b}}$ \\
With pumpkin & $14.04^{\mathrm{ab}}$ & $1.56^{\mathrm{b}}$ & $4.64^{\mathrm{c}}$ \\
With broccoli & $13.60^{\mathrm{b}}$ & $1.56^{\mathrm{ab}}$ & $4.73^{\mathrm{b}}$ \\
With red pepper & $13.80^{\mathrm{ab}}$ & $1.49^{\mathrm{b}}$ & $4.58^{\mathrm{d}}$ \\
\hline
\end{tabular}

${ }^{\mathrm{a}-\mathrm{d}}$ Mean values within each column followed by different letters are significantly different at $P<0.05$.

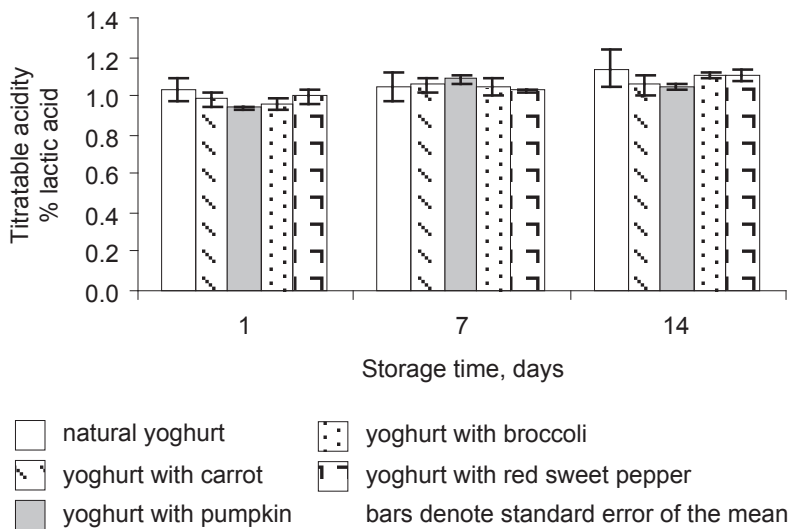

Fig. 1. Changes of titratable acidity of vegetable yoghurts during cold storage

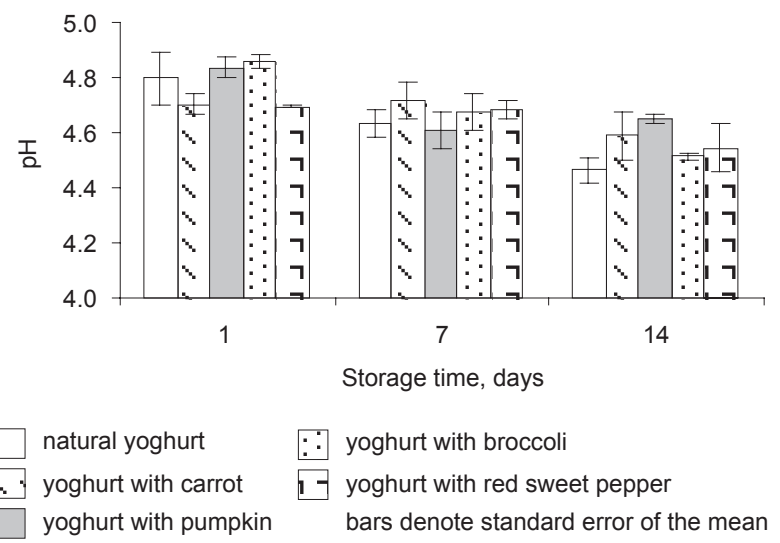

Fig. 2. Changes of $\mathrm{pH}$ of vegetable yoghurts during cold storage

6.56 - carrot, 5.38 - pumpkin, 6.67 - broccoli, 5.18 red sweet pepper (data not shown). Nevertheless, there were no significant differences detected $(P>0.05)$ in lactic acid content and $\mathrm{pH}$ values between all yoghurt types (Table 2). On the contrary, the level of these parameters was significantly $(P<0.05)$ affected by the time of storage: the $\mathrm{pH}$ level decreased and titratable acidity increased throughout the experiment duration (Table 2). The highest changes in $\mathrm{pH}$ value during cold storage were noted for the natural and broccoli yoghurts (the differences were 0.34 and $0.35 \mathrm{pH}$ units, respectively; Fig. 2). This was confirmed by the highest 
Najgebauer-Lejko D., Grega T., Tabaszewska M., 2014. Yoghurts with addition of selected vegetables: acidity, antioxidant properties and sensory quality. Acta Sci. Pol., Technol. Aliment. 13(1), 35-42.

Table 2. Least square means for $\mathrm{pH}$, the titratable acidity, antioxidant capacity (FRAP and ARP) and sensory scores in relation to the composition and storage time of yoghurts

\begin{tabular}{|c|c|c|c|c|c|}
\hline $\begin{array}{l}\text { Yoghurt type } \\
\text { / storage time }\end{array}$ & $\mathrm{pH}$ & $\begin{array}{l}\text { Titratable acidity } \\
\% \text { lactic acid }\end{array}$ & $\begin{array}{l}\text { Ferric reducing } \\
\text { antioxidant power } \\
\mathrm{mmol} \mathrm{Fe}^{2+} \cdot \mathrm{L}^{-1}\end{array}$ & $\begin{array}{l}\text { Anti radical } \\
\text { power } \\
\mu \mathrm{mol} \mathrm{TE} \cdot \mathrm{g}^{-1}\end{array}$ & $\begin{array}{l}\text { Sensory quality } \\
\text { scores }\end{array}$ \\
\hline \multicolumn{6}{|c|}{ Yoghurt type $(n=18)$} \\
\hline natural & $4.63^{\mathrm{a}}$ & $1.073^{\mathrm{a}}$ & $1.855^{\mathrm{abc}}$ & $0.257^{\mathrm{ab}}$ & $4.67^{\mathrm{a}}$ \\
\hline with carrot & $4.67^{\mathrm{a}}$ & $1.030^{\mathrm{a}}$ & $1.733^{\mathrm{ac}}$ & $0.236^{\mathrm{b}}$ & $4.53^{\mathrm{b}}$ \\
\hline with pumpkin & $4.70^{\mathrm{a}}$ & $1.023^{\mathrm{a}}$ & $1.793^{\mathrm{c}}$ & $0.196^{\mathrm{c}}$ & $4.49^{\mathrm{b}}$ \\
\hline with broccoli & $4.68^{\mathrm{a}}$ & $1.038^{\mathrm{a}}$ & $2.029^{\mathrm{b}}$ & $0.336^{\mathrm{d}}$ & $4.49^{\mathrm{b}}$ \\
\hline with red pepper & $4.64^{\mathrm{a}}$ & $1.044^{\mathrm{a}}$ & $1.939^{\mathrm{bc}}$ & $0.310^{\mathrm{d}}$ & $4.86^{\mathrm{c}}$ \\
\hline \multicolumn{6}{|c|}{ Storage time (days; $n=30$ ) } \\
\hline 1 & $4.78^{\mathrm{a}}$ & $0.981^{\mathrm{a}}$ & $2.203^{\mathrm{a}}$ & $0.268^{\mathrm{ab}}$ & $4.59^{\mathrm{a}}$ \\
\hline 7 & $4.66^{\mathrm{b}}$ & $1.053^{\mathrm{b}}$ & $1.820^{\mathrm{b}}$ & $0.253^{\mathrm{a}}$ & $4.60^{\mathrm{a}}$ \\
\hline 14 & $4.55^{\mathrm{c}}$ & $1.091^{\mathrm{b}}$ & $1.586^{\mathrm{c}}$ & $0.280^{\mathrm{b}}$ & $4.63^{\mathrm{a}}$ \\
\hline
\end{tabular}

${ }^{\mathrm{a}-\mathrm{d}}$ Mean values within each column followed by different letters are significantly different at $P<0.05$.

increment of the titratable acidity observed for the yoghurt with broccoli $(0.15 \%$ lactic acid; Fig. 1$)$.

All vegetable yoghurts directly after production showed higher ferric reducing ability compared to plain, non supplemented yoghurt (Fig. 3). Significantly higher $(P<0.05)$ than for other treatments values were stated for products with broccoli $(2.48 \mathrm{mmol}$

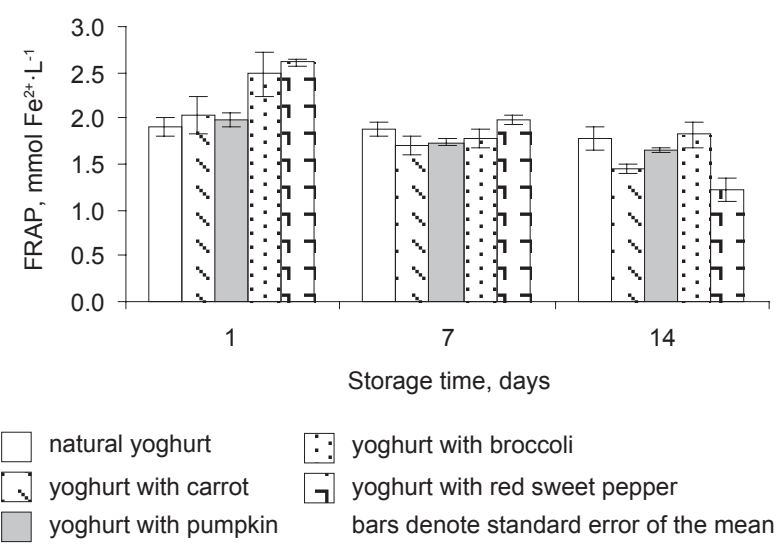

Fig. 3. Changes of FRAP value of vegetable yoghurts during cold storage
$\left.\mathrm{Fe}^{2+} \cdot \mathrm{L}^{-1}\right)$ and red sweet pepper $\left(2.61 \mathrm{mmol} \mathrm{Fe}{ }^{2+} \cdot \mathrm{L}^{-1}\right)$. These findings are consistent with data found in literature [Halvorsen et al. 2006] on the antioxidant properties of selected vegetables. Halvorsen et al. [2006] reported the following ferric reducing antioxidant power (FRAP) values for processed carrots (cut, frozen and boiled), broccoli (cooked) and red pepper (cooked): $0.099 ; 1.000$ and $1.640 \mathrm{mmol}$ of electrons/ hydrogen atoms per $100 \mathrm{~g}$ of sample, whereas the FRAP value determined for plain yoghurt amounted to $0.039 \mathrm{mmol} / 100 \mathrm{~g}$. In the same report, red pepper is mentioned in a group of 50 food products with the highest antioxidant content. The major substances which account for the antioxidant capacity in selected vegetables are: ascorbic acid, carotenoids ( $\beta$-carotene, capsanthin, capsorubin, cryptocapsin), neutral phenolics and flavonoids (quercetin, luteolin, capsaicinoids) in red sweet pepper [Deepa et al. 2006], flavonoids in broccoli [Sun et al. 2007], phenolics (primarily chlorogenic acid) as well as $\alpha$ - and $\beta$-carotene in carrots [Sun et al. 2009], $\alpha$ and $\beta$-carotene and lutein in pumpkins [Murkovic et al. 2002]. In addition to the presence of valuable nutrients milk also contains compounds which act as antioxidants, such as bioactive peptides derived both from casein and whey proteins, 
lactoferrin, urate, coenzyme Q10, vitamin C, vitamin $\mathrm{E}, \beta$-carotene, and enzymatic systems (superoxide dismutase, catalase and glutathione peroxidase) [Chen et al. 2003, Lindmark-Månsson and Åkesson 2000, Pihlanto 2006]. The antioxidant properties of milk yoghurt can be further improved, as it was demonstrated that some species of lactobacilli present in fermented milk products also possess antioxidant potential resulting probably from their high chelating activity for both $\mathrm{Fe}^{2+}$ and $\mathrm{Cu}^{2+}$ ions [Kullisaar et al. 2002, Zhang et al. 2011].

However, along with the duration of refrigerated storage the antioxidant capacity of vegetable yoghurts significantly decreased, whereas FRAP values measured for natural yoghurt maintained almost at the same level (Fig. 3). In the case of yoghurt with red sweet pepper the highest decrease of FRAP value (above $50 \%$ ) after 14 days was observed.

The antioxidant power of the obtained yoghurts measured as DPPH radical scavenging ability was much more stable during storage than iron reducing properties (Table 2, Fig. 4). This may be due to the contribution of different antioxidant substances in FRAP and ARP values. FRAP assay allows the estimation of only the water-soluble antioxidant fraction and does not take into account lipophilic substances like carotenoids [Deepa et al. 2006] which are present in the significant amount in vegetables selected for this study. Cichosz et al. [2004] while studying the total antioxidant status of milk products (milk, cream) against ABTS radical observed that antioxidants of the lipophilic phase were more stable during refrigerated storage than those present in the water phase. The greatest anti radical power (ARP) values were stated in yoghurts which contained broccoli and red sweet pepper.

The mean sensory scores for plain and vegetable yoghurts are shown in Figure 5. Additionally, mean scores (in 5-point scale) of the certain sensory attributes calculated for the whole storage period are presented in Figure 6. Generally, vegetable yoghurts received high organoleptic acceptance. The sensory quality of the obtained products was even better after 2 weeks of storage, except for broccoli yoghurt which was less acceptable at the end of the study due to its sour taste. This is probably due to the fact that consumers need some time to get used to yoghurts with vegetables as most commercially available flavoured fermented milks are sweetened. Results of many studies [Tu et al. 2010] suggest that consumers tend to give higher ratings to domestic products (e.g. biscuits) rather than to unfamiliar ones. Consequently, consumers acceptance can be improved by increasing their familiarity with the food product through repeated exposure. In the study of Salwa et al. [2004] yoghurt supplemented with $5-20 \%$ carrot juice was highly acceptable by the consumers first of all due to its sweet and pleasant taste. In our study, red sweet pepper yoghurt got

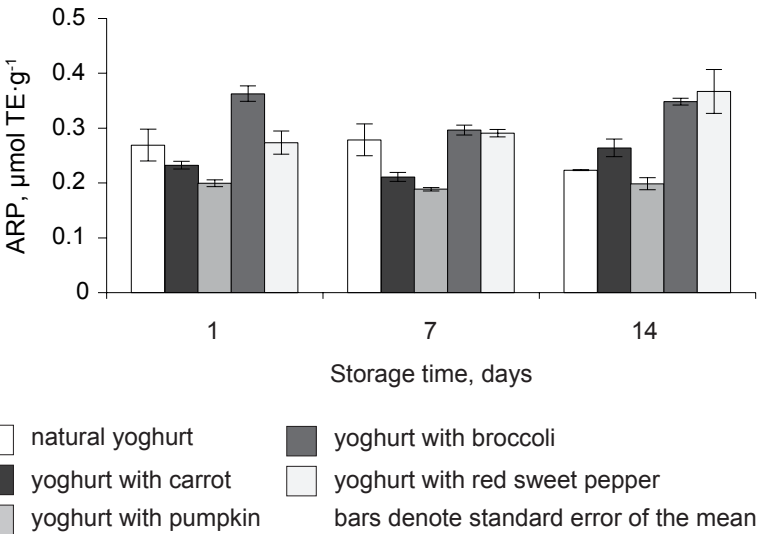

Fig. 4. Changes of ARP of vegetable yoghurts during cold storage

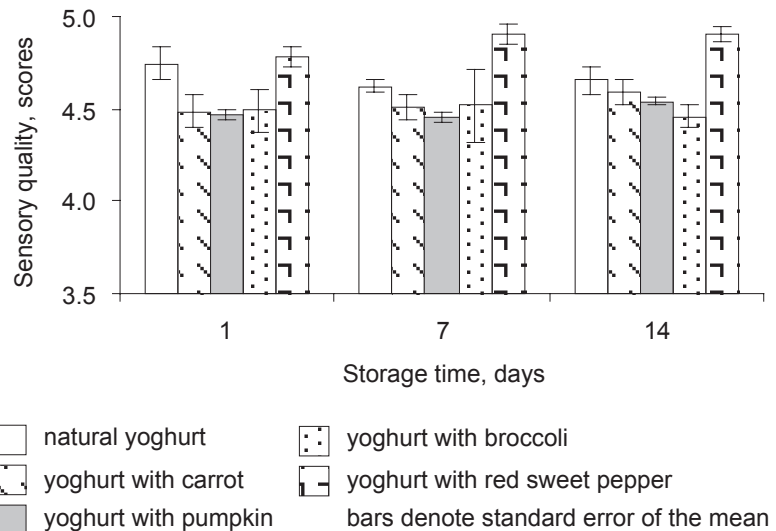

Fig. 5. The results of sensory evaluation of vegetable yoghurts during cold storage 


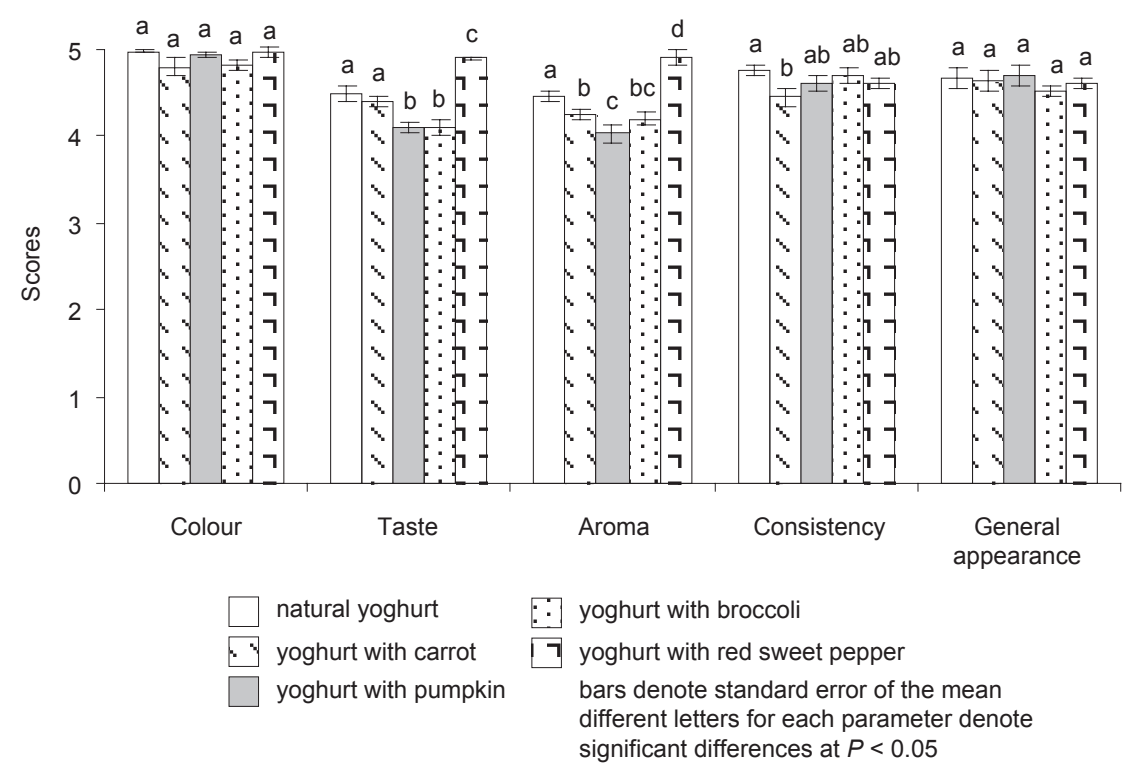

Fig. 6. Mean values of sensory parameters of vegetable yoghurts for the whole storage period

the highest scores in sensory evaluation. Other vegetable yoghurts were less appreciated than the natural one by the panellists. Data presented in Table 6 indicate that taste and aroma were there the parameters which had the highest impact on the general acceptance of the produced yoghurts. On the other hand, addition of vegetables did not produce any defects connected with colour or general appearance (e.g. whey separation) when compared to the plain yoghurt.

\section{CONCLUSIONS}

The yoghurt enrichment with selected vegetables had no significant effect on the $\mathrm{pH}$ and titratable acidity. The highest antioxidant capacity was noticed for yoghurts with broccoli and red sweet pepper. All vegetable yoghurts were characterised by higher ferric reducing ability measured directly after production when compared to the natural yoghurt but the FRAP value significantly decreased after 1 and 2 weeks of cold storage. Thus, it is recommended that to obtain the greatest health benefits of vegetable yoghurts these products should be consumed in a short time after manufacturing. Among all examined vegetables addition of the red sweet pepper was the most beneficial concerning antioxidant activity as well as sensory properties of yoghurts.

\section{REFERENCES}

Arkhipova A.N., Krasnikova L.V., Veretnov B.Y., 1995. Properties of cultured milk products with vegetable additives. Molochn. Promyshl. 3, 9-10.

Czapski J., 2001. Owoce i warzywa - szansa czy zagrożenie [Fruits and vegetables - opportunity or threat]. Żywn. Nauka Techn. Jakość 4 (29), 29-39 [in Polish].

Chen J., Lindmark-Månsson H., Gorton L., Åkesson B., 2003. Antioxidant capacity of bovine milk as assayed by spectrophotometric and amperometric methods. Int. Dairy J. 13, 927-935.

Cichosz G., Czeczot H., Giczewska M., 2004. Wartość biologiczna mleka - ocena poprzez pomiar całkowitego statusu antyoksydacyjnego [Biological value of milk an estimation through the measurement of total antioxidant capacity]. Przegl. Mlecz. 2, 4-8 [in Polish].

Deepa N., Kaur C., Singh B., Kapoor H.C., 2006. Antioxidant activity in some red sweet pepper cultivars. J. Food Compos. Anal. 19, 572-578.

Domagała J., 2011. Influence of lactation period on texture, microstructure and susceptibility to syneresis of goat's milk yoghurt. Milchwissenschaft 66, 29-32. 
Grochulska C., 2008. Mleczna droga - raport o produktach mlecznych [Marketing milk - report on dairy products]. Fresh Cool Market 5, 18-25 [in Polish].

Halvorsen B.L., Carlsen M.H., Phillips K.M., Bøhn S.K., Holte K., Jacobs Jr D.R., Blomhoff R., 2006. Content of redox-active compounds (ie, antioxidants) in foods consumed in the United States. Am. J. Clin. Nutr. 84, 95-135.

Kullisaar T., Zilmer M., Mikelsaar M., Vihalemm T., Annuk H., Kairane C., Kilk A., 2002. Two antioxidative lactobacilli strains as promising probiotics. Int. J. Food Microbiol. 72, 215-224.

Lindmark-Månsson H., Åkesson B., 2000. Antioxidative factors in milk. Brit. J. Nutr. 84 (Suppl. 1), 103-110.

Lucas A., Rock E., Chamba J.-F., Verdier-Metz I., Brachet P., Coulon J.-B., 2006. Respective effects of milk composition and the cheese-making process on cheese compositional variability in components of nutritional interest. Lait 86, 21-41.

Moon J.K., Shibamoto T., 2009. Antioxidant assays for plant and food components. J. Agric. Food Chem. 57, 1655-1666.

Murkovic M., Mülleder U., Neunteufl H., 2002. Carotenoid content in different varieties of pumpkin. J. Food Compos. Anal. 15, 633-638.

Pihlanto A., 2006. Antioxidative peptides derived from milk proteins. Int. Dairy J. 16, 1306-1314.

PN-A-86061:2002. Mleko i przetwory mleczne - Mleko fermentowane. [Polish standard PN-A-86061:2002. Milk and milk products. Fermented milk; in Polish].

Salwa A.A., Galal E.A., Neimat A.E., 2004. Carrot yoghurt: Sensory, chemical, microbiological properties and consumer acceptance. Pak. J. Nutr. 3, 322-330.
Shereshevsky M., 2005. Ready to eat food formulation containing yogurt and pureed cooked vegetables and process of manufacture thereof. US Patent US 2005/0226987 A1.

Skrede G., Bryhn Larsen V., Aaby K., Skivik Jørgensen A., Birkeland S.E., 2004. Antioxidative properties of commercial fruit preparations and stability of bilberry and black currant extracts in milk products. J. Food Sci. 69, S351-S356.

Song W., Derito C.M., Liu M.K., He X., Dong M., Liu R.H., 2010. Cellular antioxidant activity of common vegetables. J. Agric. Food Chem. 58, 6621-6629.

Stankiewicz J., 2009. Jakość mlecznych napojów fermentowanych suplementowanych dodatkami pochodzenia roślinnego [The quality of fermented milk drinks supplemented with plant extracts]. Zesz. Nauk. Akad. Morsk. Gdyn. 61, 39-44 [in Polish].

Sun T., Powers J.R., Tang J., 2007. Evaluation of the antioxidant activity of asparagus, broccoli and their juices. Food Chem. 105, 101-106.

Sun T., Simon P.W., Tanumihardjo S.A., 2009. Antioxidant phytochemicals and antioxidant capacity of biofortified carrots (Daucus carota L.) of various colors. J. Agric. Food Chem. 57, 4142-4147.

Tamime A.Y., Robinson R.K., 1999. Yoghurt. Science and Technology. Woodhead Publ. Cambridge, UK.

Tu V.P., Valentin D., Husson F., Dacremont C., 2010. Cultural differences in food description and preference: Contrasting Vietnamese and French panellists on soy yogurts. Food Qual. Prefer. 21, 602-610.

Zhang S., Liu L., Su Y., Li H., Sun Q., Liang X., Lv J., 2011. Antioxidative activity of lactic acid bacteria in yogurt. Afr. J. Microbiol. Res. 5, 5194-5201.

\section{JOGURTY Z DODATKIEM WYBRANYCH WARZYW: KWASOWOŚĆ, WŁAŚCIWOŚCI PRZECIWUTLENIAJĄCE ORAZ JAKOŚĆ SENSORYCZNA}

\section{STRESZCZENIE}

Wstęp. Jogurt jest mlecznym napojem fermentowanym o wyjątkowych walorach sensorycznych, odżywczych i dietetycznych oferowanym w różnej formie oraz w wielu smakach. Warzywa należą do grupy produktów bogatych w składniki o silnych właściwościach przeciwutleniających (np. witamina C, karotenoidy, tokoferole, polifenole), których spożywanie w odpowiedniej ilości zmniejsza ryzyko występowania wielu schorzeń, w tym nowotworów i chorób układu krążenia. Celem pracy było wyprodukowanie oraz określenie kwasowości, jakości sensorycznej oraz właściwości przeciwutleniających jogurtów z dodatkiem wybranych warzyw w trakcie 2-tygodniowego okresu przechowywania chłodniczego.

Materiat i metody. Przeciery warzywne (z marchwi, dyni, brokuła oraz czerwonej papryki) w ilości 10\% wag. dodano do mleka fermentowanego z użyciem kultury jogurtowej typu DVS po wstępnym ochłodzeniu do $15-20^{\circ} \mathrm{C}$. Analizy obejmowały: oznaczenie $\mathrm{pH}$ i kwasowości miareczkowej, aktywności przeciwutleniającej 
Najgebauer-Lejko D., Grega T., Tabaszewska M., 2014. Yoghurts with addition of selected vegetables: acidity, antioxidant properties and sensory quality. Acta Sci. Pol., Technol. Aliment. 13(1), 35-42.

poprzez określenie zdolności redukcji jonów żelaza (FRAP) oraz eliminacji rodników DPPH, analizę sensoryczną i były przeprowadzone po 1,7 oraz 14 dniach przechowywania chłodniczego.

Wyniki. Suplementacja przecierami z wybranych warzyw nie wpłynęła znacząco na wartość pH oraz poziom kwasowości miareczkowej jogurtów. Największą zdolnością eliminacji rodników DPPH charakteryzowały się jogurty z brokułem i czerwoną papryką. Te ostatnie uzyskały również najwyższe noty w ocenie sensorycznej. W pierwszym dniu analiz wszystkie jogurty z dodatkiem warzyw wykazywały większe wartości FRAP w stosunku do jogurtu naturalnego, ale wartość tego parametru obniżyła się znacznie po przechowywaniu. Wnioski. Spośród wszystkich badanych warzyw, dodatek czerwonej papryki najkorzystniej wpłynął na właściwości przeciwutleniające oraz akceptowalność organoleptyczną jogurtów.

Słowa kluczowe: DPPH, FRAP, warzywa, jogurt, jakość sensoryczna

For citation - Do cytowania

Najgebauer-Lejko D., Grega T., Tabaszewska M., 2014. Yoghurts with addition of selected vegetables: acidity, antioxidant properties and sensory quality. Acta Sci. Pol., Technol. Aliment. 13(1), 35-42. 